\title{
"Bastard" daughters in the Ivory Tower: Illegitimacy and the higher education experiences of the daughters of single mothers in the UK
}

\author{
Jessica Dawn Gagnon ${ }^{1}$ \\ School of Education and Social Work, University of Sussex, Brighton, United Kingdom
}

\begin{abstract}
:
Underrepresented students are often constructed through deficit discourses and blamed for "lowering the bar" in higher education (Burke 2012). If a student struggles, then that may be seen as proof of personal deficiencies - proof of her illegitimacy -- and not of a system that is built to exclude her. This article explores notions of legitimacy within the university experiences of the daughters of single mothers who are first generation students through a thematic analysis of semi-structured interviews with and reflective writings from 26 undergraduate students in the United Kingdom. The theoretical and conceptual frameworks upon which this study is built include feminist theory, intersectionality theory, and the concept of social exclusion. The findings have implications for pedagogical practices in higher education. Changes should be made to create more equal learning environments not only for this underrepresented group, but also for other student groups who feel illegitimate in higher education.
\end{abstract}

Keywords: higher education; underrepresented students; student experience; inequality; family

\section{Introduction: The personal is political}

I am illegitimate, a bastard, a child born out of wedlock. Synonyms for "bastard" include scoundrel, villain, and wretch. I am illegitimate - it is not only my status as the daughter of an unwed, single mother but it is also how I feel within academia. My higher education experiences have made me feel like my presence, as a first generation student from a working-class, single mother family, bastardises academia itself. Within this article I explore both legitimacy as it specifically relates to family status as well as notions of legitimacy within higher education more generally. Throughout this article I ask you to consider: In what ways are the cultures and practices of higher education reinforcing norms about who is recognised and who is misrecognised, about who is and who is not legitimate within the ivory tower? While this research has resonance on a political level, on a social level, and on a scholarly level, it is also deeply personal, which is why I have chosen to introduce the research through the personal lens first. As Butler wrote $(1988,522)$ :

The feminist claim that the personal is political suggests, in part, that subjective experience is not only structured by existing political arrangements, but effects and structures those arrangements in turn. Feminist theory has sought to

\footnotetext{
${ }^{1}$ After completing this research, the author changed affiliations to the School of Education and Childhood Studies, University of Portsmouth, Portsmouth, United Kingdom
} 
understand the way in which systemic or pervasive political and cultural structures are enacted and reproduced through individual acts and practices, and how the analysis of ostensibly personal situations is clarified through situating the issues in a broader and shared cultural context.

Individual experiences are impacted by the historical, social, and political contexts in which they occur and can contribute to the perpetuation or maintenance of unequal social and political systems. In discussing my status as an illegitimate child, my lived experiences, my identity and my story are tied inextricably to the larger political and social worlds that construct, define, misrecognise, and limit me. It is important to note that the women in this study each have unique histories, identities, and experiences. Their mothers became single mothers for a variety of reasons, including divorce, bereavement, and abandonment. However, they are all impacted by dominant, homogenising discourses and representations of who is and who is not recognised as legitimate.

Findings from the 2011 UK census indicate that single parent families represent one out of every four families with children ( 26 percent) and "women accounted for 92 percent of lone parents" (Office for National Statistics 2012, 5). Single mothers and their children are more likely to live in poverty than their two-parent household counterparts (Maplethorpe et al. 2010). The nuclear family as norm is more myth than reality as family units are fluid and changing (Hampden-Thompson and Galindo 2015; Biblarz and Stacey 2010). Yet popular discourse still clings to the concept of the heterosexual nuclear family as if it is the norm against which all other families can be judged and punished for nonconformity.

Academia has been partly complicit in the negative social construction of single mothers and their families by almost exclusively discussing their children's educational achievements in negative terms, constructing them through deficit discourses. For example, some studies have suggested that the children of single mothers are less likely to participate in higher education (Martin 2012; Ringback Weitoft, Hjern, and Rosen 2004). Yet many of those studies ignore economic issues that constrain children's educational outcomes and fail to question the assumption, held as truth, that the married, heterosexual nuclear family form is best for children's educational outcomes. Findings by Hampden-Thompson and Galindo (2015), showed that children can thrive in a variety of family units, regardless of the number or the gender of their parents. As Biblarz and Stacey explained (2010, 17):

Current claims that children need both a mother and father are spurious because they attribute to the gender of parents benefits that correlate primarily with the number and marital status of a child's parents since infancy. At this point no research supports the widely held conviction that the gender of parents matters for child well-being. To ascertain whether any particular form of family is ideal would demand sorting a formidable array of often inextricable family and social variables.

The failure of many researchers to recognise families as complex rather than homogenous groups allows for the continued social construction and misrecognition of single mothers and their families as deficient or deviant compared with the more highly valued norm of married heterosexual nuclear families. For the women in this study, constructed norms around who is recognised as legitimate as a student (Burke 2012) collide with the ways the nuclear family is also constructed as norm. Both serve as obstacles to overcome for the participants throughout their education. 


\section{Legitimacy and "bastard" daughters: Some things never change}

Within this subsection I present a brief history of legitimacy laws and the treatment of single mother families in Britain carrying through to modern day examples to highlight the ways some things never change. For centuries, the existence of single mothers and their children has been perceived as a threat to the nation (Edwards and Caballero, 2011). The Special Bastardy Act within the Statute of Merton in England in 1235 confirmed the long-held definition: "He is a Bastard that is born before the Marriage of his Parents" (Evans 1817, 174). The section of the Statute clarified that while the church allowed a child born out of wedlock to become legitimate under the eyes of God if his parents were married after his birth, the civil laws of England still considered all children born out of wedlock to be bastards (Merton Historical Society 2001).

Nearly 800 years after that first bastard's law was passed, some children born out of wedlock are still unwelcome in modern day Britain. Children like Ella Mullin, whose story was revealed in news coverage in September 2017 (Duffy 2017). Ella was born in Liverpool to a Canadian mother and a British father. While her parents later married after she was born, Ella was told she has no citizenship rights. She was born in Britain and has spent her entire life in Britain, but she was not considered a British citizen because of an existing legitimacy law.

Children born out of wedlock were so undesirable in England that a law was passed by Parliament in 1773 titled "A bill for better regulating the settlement and providing for the maintenance of bastard children", which made it illegal to continue the common practice of church and community leaders forcing pregnant unwed women to leave the parish as their children were considered a burden to the community (Parliament of Great Britain 1773). Church leaders supposedly bound by Christian values, were forcing women and their children to become placeless, homeless, to belong nowhere.

Fast forward to September 2014 when a group of single mothers within Newham, part of the city of London, on the verge of homelessness, overtook and occupied an empty block of council flats. The activists, called the Focus E15 mothers, received widespread media attention and used their platform to draw attention to the growing trend in the UK capital of councils forcing precarious families to either leave the city or become homeless and destitute. Explaining the frightening ultimatum that the women and their children were given by the council, Jensen (2014) wrote:

The mothers were informed that the financial support paid by Newham Council towards their accommodation would be cut and they were served notices to leave by the Housing Association which manages the hostel. ... Some of the women were offered accommodation in cheaper parts of the country - including Hastings, Manchester and Birmingham - and were told that, if they refused such an offer, they would be considered to have made themselves 'intentionally homeless', thus freeing Newham Council from any further obligations to help them. Some of the women were in the hostel because they were escaping domestic violence, yet they were described as 'not vulnerable, but needy'.

The Focus E15 mothers pointed out that they had families, friends, and support networks in and around Newham and that many of them had grown up there. They belonged in Newham. They had no connections to the cities to which the council had tried to banish them, much like the community leaders in the 1700s had done to single mothers (Parliament of Great Britain, 1773). 
Victorian understandings of single mothers as "deviant" were explicated in an exhibition titled "The Fallen Woman" (The Foundling Museum 2015):

In 1836 the Marriage Act extended the definition of legal marriage to include civil ceremonies held at the register offices, thus reinforcing the differences between the respectable and the non-respectable [woman]. This made the figure of the unmarried mother especially deviant and anti-social. ... The figure of the "fallen woman" thus challenged the social, moral and sexual norms of Victorian society and threatened the image of the happy family home which was regarded as the secure base for both the nation and the empire.

In Victorian Britain, unmarried mothers were a "threat" to the "happy family home" as well as to the "nation and the empire". More than a century later, the notion that certain individuals and families were a "threat" to the nation was mirrored in debates around Section 28 legislation in Britain, which was passed in 1988. The legislation defined a "real" family as a husband, wife, and child. Families that deviated from the idealised norm, such as same sex couples or single parent families, were classed as "pretend families" that were supposedly "corrupting" society (Reinhold 1994, 62). Section 28 was not repealed fully until 2003, so that legislation had an impact on which families were recognised as legitimate during the lifetimes of the participants in this study.

The practice of scapegoating, stereotyping, and stigmatising single mothers and their families within the Western World continues today, especially in political and media discourses. For example, through public comments made by American conservative politician Rick Santorum who stated that single mothers are "breeding more criminals". He suggested that, "We are seeing the fabric of this country fall apart, and it's falling apart because of single moms" (Murphy and Kroll 2012). Using even more grotesque language, conservative American radio host Rush Limbaugh (The Rush Limbaugh Show 2013) referred to single mothers as "receptacle[s] for male semen".

Single mothers were characterised as slothful, gluttonous, and dangerous within writing by Australian conservative commentator John Hirst (2013):

Many single-parent households are not good places for children. The mothers are given to junk food, daytime TV and no-good boyfriends, who might develop designs on an adolescent daughter. The worst mothers are addicted to drugs and alcohol and under their influence neglect and abuse their children.

The existence of single mothers was suggested as a cause of the destruction of society, according to UK politician John Redwood who stated that single mothers are "one of the biggest social problems of our day" (Rowling 2010), which he stated before divorcing his wife and thus turning her into a single mother. After the 2011 London riots, then conservative Prime Minister David Cameron blamed the unrest on "families without fathers" that were causing a "moral collapse" in British society (Thane and Evans 2012, 206).

While many of the examples of politicians and public figures making derogatory statements about single mothers and their children represent religiously-influenced, conservative notions of what makes a 'good' woman, a 'good' mother, and a 'good' family, their views are not simply those of societal outliers. They are given public and popular platforms to continue to stigmatise and marginalise single mothers and their hateful views go largely unchallenged. The vile statements made about single mothers I have included in this article are the same words that the children of single mothers and that single mothers themselves have read and have heard repeated. I have not made the choice to include them lightly. Those words are repulsive to me as the daughter of a single mother. I feel them viscerally, like a punch to the stomach. 
While much has been written about bastard sons, there is also a history of women being branded as illegitimate, a history of bastard daughters (Yukins 2002). The experiences of bastard children were, and, in many ways, still are, highly gendered. Historically, many of the rights denied to bastard children, such as the right to noble title, to succession, to land and other forms of inheritance, were focused on male children (Spillers 1987). Considering those gendered differences, Spillers argued that female children cannot actually be considered bastards (1987). Yukins $(2002,225)$ provocatively challenged the notion that women cannot be bastards:

Spillers's analysis provokes a paradoxical question: If women are not considered legitimate claimants to patriarchal inheritance, then are women not bastards or are all women bastards?

As legitimacy is gendered, seen as the purview of men, then are women ever bastards or, as Yukins asked, "are all women bastards?" The question resonates with the ways women are still marginalised and made to feel illegitimate in so many facets of our lives, connected, in this study, to the feelings of illegitimacy within higher education.

\section{Legitimacy and higher education: Bastardising the academy}

Students from underrepresented backgrounds within academia are often constructed as illegitimate and scapegoated as the reason higher education is deteriorating (Burke 2012). Underrepresented students are blamed for "lowering the bar" and "dumbing down" the academy (Burke 2012). "Students from non-traditional backgrounds are seen as being frequently perceived as a risk to universities and to the state that invests in them" (Hinton-Smith 2012, 12). Fingers point to underrepresented students when academic standards are discussed because they have supposedly polluted or poisoned the system, resulting in poor and worsening standards. The claim perpetuated is that the presence of underrepresented students in university classrooms "bastardises" the quality and excellence of higher education itself.

Alongside these ghost stories of the dreaded underrepresented student poisoning the prestige of higher education is the myth of the underrepresented student simply needing to be more aspirational if she is to be successful in the academy. It is this myth that perpetuates the neoliberal fallacy that if a student from an underrepresented background is simply ambitious enough, aspirational enough, hard-working enough, determined enough, then she will surely be successful, no matter the odds stacked against her. As Burke (2012 105) explained:

The emphasis on individual aspirations misses out the significant interconnections between a subject's aspirations and their classed, racialized, (hetero)sexualized and gendered identities, ignoring their social, spatial and cultural contexts in which certain subjects are constructed, and construct themselves, as having or not having potential.

Students who struggle once they enter academia are seen as lacking "resilience" and are constructed through deficit discourses (Burke 2012). If she is not successful, then it is proof of a personal failing, proof of her illegitimacy, and not of a system that is built to exclude her.

\section{Methodology}

This article explores notions of legitimacy and misrecognition within the university experiences of the daughters of single mothers who are first generation students through a thematic analysis of semi-structured interviews with and reflective 
writings from 26 undergraduate students in the United Kingdom. Single mother families are diverse and can be formed and defined in many ways. To allow for the diversity of single mother families, through my recruitment efforts I sought participants who met the following criteria:

- Considered themselves to have been primarily raised by their mother (or their mother raised them alone for about five years or more during their childhood)

- Were current or recent undergraduate university students at any university in the UK, any mode of study (full or part time), and any age (traditional age or mature students) at the time of the data collection

- Were first-generation students (the first in their family to attend university, which includes students whose siblings might have gone to university)

Using this criteria, I intentionally chose to seek participants who self-identified as the daughters of single mothers. The length of time was chosen based on previous studies (Ridge and Millar 2011; Ringback Weitoft, Hjern, and Rosen 2004). I sought to interview current or recent undergraduates (defined, for this study, as those who have completed their undergraduate studies within the five years prior to the interview) as I wanted their undergraduate experience to be both relevant to the current state of higher education in the UK and fresh in their memories. Most of the interviewees (22) were currently pursuing their undergraduate studies at the time of the interview with a few (4) having recently completed their degree.

Data was collected for this doctoral research during late spring and summer of 2013. A preliminary 30-question, online questionnaire, provided some quantitative and qualitative data from 110 respondents. The 26 interview participants were pursuing or had recently completed an undergraduate degree in the United Kingdom. They were attending or had attended a wide variety of universities (21), representing the spectrum of university statuses and reputations, such as post-1992 universities (former polytechnical universities) and Russell Group universities (higher status, more selective universities), and were pursuing or had completed a diverse range of undergraduate degrees in 16 subject areas including sociology, education, psychology, film and media studies, chemistry, archaeology, physics, maths, photography, sculpture, and law. Among the participants, most were or had studied full time (24) and two were part time students. The interview participants represent a mix of traditional age (17) and mature students (9). Among them, 20 identified as White and 6 identified as BME (Black Minority Ethnic). The racial and ethnic make-up of single parent families in the United Kingdom is 90 percent White and 10 percent BME (Maplethorpe et al. 2010, p. 22). As far as socio economic class, 19 participants identified as working class and 5 identified as middle class. Two of the participants indicated that they were uncertain about their socio economic identity. After the interview, participants were provided writing prompts and questions and encouraged to engage in reflective writing as part of the third method of data collection.

The theoretical and conceptual frameworks upon which this study is built include feminist theory (Butler 1988), intersectionality theory (Yuval-Davis 2006; Crenshaw 1989), and the concept of social exclusion (Byrne 2005). For this research, I chose to especially focus on the concept of misrecognition (Burke 2013; Burke 2012; Butler 2001). Data was explored through a thematic (Frost 2011) analysis.

The 26 interviewees who took part in this study came from diverse family backgrounds and their mothers were raising them primarily on their own for various lengths of time and were on their own for a variety of different reasons, including divorce, bereavement, and abandonment. Yet, even the participants who were not born out of wedlock, whose mothers became single mothers through divorce or bereavement, 
faced the same stigmas by association with those born and raised without a father. For example, Marilyn, a participant in this study whose father had died, talked about the pain of feeling the need to tell complete strangers about his death in order to feel like her family would be seen as 'respectable' enough and spared the full judgment reserved for unwed mothers and their children. Within media, political, and social discourses, single mothers and their families are seen as one homogenous group, shackled by the same stereotypes and judgments against which they fight for recognition, fight for legitimacy.

\section{Legitimacy in the data: Pretending to fit in}

Within this study, a number the participants suggested that it may be easier for the daughter of a single mother to try to "pass" as part of the privileged, two-parent student population. I asked the participants about how, when, and to whom they disclose their status as the daughter of a single mother. Many discussed keeping this part of their lived experience and identity a secret from people until they thought they could trust that the person to whom they chose to disclose would not negatively judge them. Kiersten, a white, middle class, traditional age student, talked about being "afraid" to disclose her family background:

I've pulled myself up but because people now don't see me ... like my friends like they don't know my family. ... Being in university, sort of, it's more of a middle class thing and that everyone else ... was sort of from a nuclear family, so I think that was more why [I don't disclose], whereas if I were at home I wouldn't, I wouldn't be, I wouldn't be afraid to say it.

Vera's response was similar to Kiersten's. When I asked the question: "What do you hope to gain by going to university?" Vera, a white, working class, traditional age student, without pausing, proclaimed her answer as one word: "Respectability". I asked her to elaborate.

I'm from a working class background and single parent family and I think it's kind of interesting for me to look around me and see how I'm not the norm there [at university]. ... It's been interesting for me to try and almost pretend that I'm from the same background as everyone else, like just to try to fit in, to strive to be a part of that.

Vera's words echo the work by Skeggs (1997) on working class women and the determination to be seen and recognised as "respectable". "Class becomes internalised as an intimate form of subjectivity, experienced as knowledge of always not being "right"” (Skeggs 1997, 90). In Vera's case, she talks about trying to pass, to "almost pretend" to be "the same ... as everyone else". She indicates that her background, growing up working class in a single parent family, is not consistent with the norm at university and that she must, therefore, earn respectability through mimicking the students from middle class, nuclear families.

Similarly, Amy, a white, working class, traditional age student, talked about university as a space where students can try to shape how they are perceived by "passing":

That's the brilliant thing about that first day [at university] -- when you know nothing about anybody. You can be who you want, and that isn't about class. That's about you as an individual. So, you can dress how you want. You can talk about what music you listen to. You only reveal a certain amount of those things about you. ... There's nothing related to your background about that. ... I don't mean it's a case of trying to blend in and trying to be different to what you are, 
but you, you reveal certain things about you. You shape the person you want people to think - and it's not a lie, it's just the you that you want to be. ... Like, the single parent thing didn't come up for me for a very long time at Uni. ... You just try to present yourself in the way you want people to see you, I guess.

For Amy, in the first days at university, what she chose to "reveal" about herself was carefully negotiated so that her peers would see her in the ways that she wanted to be seen. What I understood when Amy said: "It's not a lie, it's just the you that you want to be" was that Amy wanted her peers to recognise her true self, to see her self-defined identity, before their perceptions of her were tainted by stereotypes and prejudice.

For many participants, the choice to keep their family status private was influenced by negative reactions when they had disclosed previously, as illuminated in these quotes by Holly and Jeanette, both white, working class, traditional age students:

Holly: When people find out that I just have my mum, they normally can't comprehend. ... They're like: "Oh, I didn't realise. You don't seem ... messed up. You don't seem damaged. You don't seem fucked up".

Jeanette: I was always sort of praised for doing well despite of my circumstances. ... Like somehow having a single parent family made me an idiot, like "Oh, haven't you done well getting into university?" Like, why would that have a bearing on whether my mother was single or not? I mean, I'm independent of my mother. I'm a different person, you know.

The interviewees did not want their family status to change how people viewed them. As Jeanette's quote makes clear, she wanted to be recognised for her accomplishments, not patronised for what she achieved as if she did well "despite" her "circumstances". She wanted to be recognised as legitimate among her university peers, without people assuming that her status as the daughter of a single mother meant that her accomplishments were unexpected or extraordinary.

Identity is constructed through many lenses, reflecting, refracting, filtering, distorting how we see, know, and understand our selves and how the world sees and judges us (Lawler, 1999). Who I am is not a declaration I make without being challenged by a world that sees me differently than I see myself. For the participants within this study, understanding and defining identity is complicated and emotional. Identity is a performance that involves pronouncements, negotiations, protestations, and affirmations (Butler, 1997). Trying to "pass" was one of methods by which the participants attempted to avoid misrecognition and assert their self-defined identities.

As another method of trying to "pass" at university, many of the women in this study discussed trying to hide, change, soften, or "lighten up" their accents so that academia might find them more suitable. They are forced to be chameleons, to speak "like the Queen", as one participant, Audrey, put it, to adapt to the norms privileged through elitism within the ivory tower. As Lawler wrote (1999, 17):

There is always the danger that you might not pass; that someone might "see through" you. Accents are a particular pitfall here, particularly in Britain, where they (are assumed to) clearly mark social location.

Amber, a BME, working class, mature student, talked about tutor favouritism of privileged students and the ways she felt judged by her accent and class background in the classroom.

The lecturer always knew the names of them [private school educated] students. Always. Always talked up to them more, so you'd always find the same people talking [in class], but I think that's because the lecturer would think they were more intelligent. ... It's the words you use as well. So, for example, say that you 
can't articulate yourself properly. You're as intelligent as the other person, but because you haven't had the same schooling or haven't had the same upbringing, they all think that person clearly knows more than you. ... I feel intimidated to talk to them [lecturers], and then sometimes I think they'll think I'm stupid. And that sounds silly, but I think that they'll think I'm stupid - or I don't put my hand up [in class] because I don't want ... people to laugh at me. ... There's a girl in my class, and ... she's from Peckham. When she speaks, I can see everyone laughing. ... And I'm thinking to myself, this girl has tried so hard to get here, and you all are just laughing at her. I don't want them to do that to me, because I feel like, because I don't speak the same accent or I don't pronounce my Ts.

Adopting middle class mannerisms, ways of speaking and writing, ways of knowing and understanding, does not give a working class student access to the privileges and benefits that come with actually being middle class. Amber would rather be silent in class than face judgment. She wants her intelligence to be recognised, but her accent and vocabulary and social class background become the means by which she feels she is identified as illegitimate in academia.

In addition to students who face classism within the academy, some students encounter racism in overt and covert ways. For some of the women in this study, their racial and ethnic identities shaped how the world sees them and how they see themselves. The impact of systemic racism can be felt in many aspects of the lives of BME women, including within their higher education experiences (Alexander and Arday 2015). Heather, a BME, working class, traditional age student, discussed her class, race, and family status as they impacted on her experience in university:

Honestly, I still - I don't feel like I belong. ... I mean, I'm not very well spoken, so sometimes I feel a bit put down when people start using big words, and I think, I don't - that's not how I speak. At the same time, I'm an ethnic minority, and in a class full of white people. When we talk about race, it seems like a very touchy subject. ... Some of the things that have happened to me, some of the things people have said to me, this is life experience. I don't think anyone else in my class could ever fully understand. ... They'll never fully understand how it feels to be from a working class background. I mean, as well as being an ethnic minority, and mine's a single mum, and she's also unemployed now. So all of that kind of falls into one.

In Heather's example, her identities cannot be individually examined. Her experience is bound up in the multiple ways she identifies and must be understood through that kaleidoscope of complexity. Yuval-Davis writes $(2006,200)$ that identity:

Is constructed along multiple axes of difference, such as gender, class, race, and ethnicity, [age], sexuality, and so on. ... The intersecting social divisions cannot be analysed as items that are added up, but rather as constituting each other. Although discourses of race, gender, class, etc. have their own ontological bases that cannot be reduced to each other, there is no separate concrete meaning of any social division.

Heather realises that the ways her peers use big words are proof of their worth in the classroom and become markers differentiating her background from theirs as if she is less academically legitimate. She does not see her lived experiences of social class and race being valued in class discussions. As a result, she contributes less in class and the white, middle class norms against which she is judged are strengthened and maintained as those are the voices that continue to be heard. 
Another quote from Heather and a quote from Zoe, also a BME, working class, traditional age student, further illuminate the ways race impacted upon the university experiences of some of the women in this study:

Heather: I don't want to get too racial, but some people always think [the typical student is] white, middle class. ... That's what they always think of it. I mean, you know that obviously minorities and white people go to university. But, it's mainly associated with being white and middle class. ... I came from London, and it's quite a very ethnic diverse place. And I came to university, and when I was in the first term, I was the only black person in my class. I was actually taken aback. ... I know there's other ethnic minorities on campus, but I was so taken aback. I thought, "Oh my gosh! I'm the only black person in my seminar”.

Zoe: I feel once people learn that I am from a single mother family, with brothers and sisters all by different fathers, they are careful about what they say with regards to ... not offend me. However, my closer friends are largely liberals and I don't think the fact that I'm not from a nuclear family really makes a difference to them. But certain people don't appear to be the same with regards to race and class. I have encountered more issues and awkward situations because of these things. ... They have caused me to think far more about my identity and how I am perceived by others. It is something I struggled with a lot in my first year of university

Which students are positioned as legitimate, as good, as ideal through discourses, both outside and within the university negatively impacts upon the overall higher education experiences of many underrepresented students as they continue to face misrecognition (Burke 2013) through stereotypes based on their identity categories, such as class, race, or family background. Discussing misrecognition, Butler (1997:33) wrote:

Imagine the quite plausible scene in which one is called by a name and one turns around only to protest the name: 'That is not me! You must be mistaken!' And then imagine that the name continues to force itself upon you, to delineate the space you occupy, to construct a social positionality. Indifferent to your protests, the force of interpellation continues to work. One is still constituted by discourse, but at a distance from oneself.

For many underrepresented students, their university experiences are shaped by their fears of being "outed" as not belonging, of being revealed as illegitimate compared to their peers. If they are unable to fully "blend in" or mimic those more highly valued norms, they face misrecognition by their peers and by their teachers.

\section{Implications and Conclusion}

Within this article, I have illuminated some of the university experiences of the participants within this study with a focus on notions of legitimacy, both legitimacy as it relates to family status and legitimacy as it relates to recognition and belonging at university. As the data shows, the participants are constructed through deficit discourses and their academic aspirations and abilities are often misrecognised because of the stereotypes, such as those about their family background, their accents, their social class, and their race, that they face and that they endeavour to resist. Their university experiences are often marked by many reminders, both subtle and overt, of the ways they do not fit within the "ideal" student norm, of the ways that they are misrecognised 
and made to feel like they are not legitimate.

The findings from this study have implications for policies and practices in order to address the ways that norms, about who is recognised and who is misrecognised and made to feel illegitimate, are reinforced within higher education. Academia should question the inequalities within society, not contribute to deepening and widening those inequalities further by continuing to engage in teaching, research, and administrative practices that reify social norms. Through these findings, I suggest that we, as academics, should continue to interrogate the impact of implicit biases within our institutions, such as those based on race, class, gender, and family status.

What does the data at your institution (such as: the inclusion or exclusion of a diversity of perspectives within the curriculum; applications and admissions data; withdrawal data; persistence and completion data; student feedback data; student stories about their experiences) tell you about: Whose knowledge matters at your institution? Whose voices are heard? Whose contributions are valued? Whose experiences are validated? Who is recognised and who is misrecognised and made to feel illegitimate?

These questions are just the start of the ongoing conversations we must have within academia in order to work towards creating more equal teaching, research, and administrative policies and practices within our institutions. We must continue to work towards addressing the ways some students are made to feel misrecognised, made to feel illegitimate.

Disclosure statement

No potential conflict of interest was reported by the authors.

Acknowledgements

The author wishes to thank the students who participated in this research project and her two PhD research supervisors, Professor Penny Jane Burke and Dr Tamsin HintonSmith.

\section{References}

Alexander, C. and J. Arday (eds.) 2015. Aiming higher: Race, inequality and diversity in the Academy. Runnymede Trust. Available at: http://www.runnymedetrust.org/uploads/Aiming\%20Higher.pdf [Accessed 10 September 2015].

Biblarz, T. J. and J. Stacey. 2010. How does the gender of parents matter? Journal of Marriage and Family, 72, 3-22.

Burke, P. J. 2012. The right to higher education: Beyond widening participation. Abingdon: Routledge.

Burke, P. J. 2013. The right to higher education: neoliberalism, gender and professional mis/recognitions, International Studies in Sociology of Education, 23 2,107-126.

Butler, J. 1988. Performative acts and gender constitution: An essay in phenomenology and feminist theory. Theatre Journal, 404 , 519-531.

Butler, J. 1997. Excitable speech: A politics of the performative. New York: Routledge.

Butler, J. 2001. Giving an account of Oneself. Diacritics, 31(4), 22-40.

Byrne, D. 2005. Social Exclusion. Berkshire: McGraw Hill Education.

Crenshaw, K. 1989. Demarginalizing the intersection of race and sex: A Black Feminist critique of antidiscrimination doctrine, feminist theory, and antiracist politics. University of Chicago Legal Forum, 139, 138-67. 
Duffy, T. 2017. Woman born in Liverpool told she's NOT British because of little known law. The Liverpool Echo. [online] Available at: http://www.liverpoolecho.co.uk/news/liverpool-news/woman-born-liverpooltold-shes-13562845 [Accessed 1 Nov. 2017].

Edwards, R. and C. Caballero. 2011. Lone mothers of mixed racial and ethnic children in Britain: Comparing experiences of social attitudes and support in the 1960s and 2000s. Women's Studies International Forum, 34, 530-538.

Evans, W. D. (ed.) 1817. A collection of statutes connected with the general administration of the law; arranged according to the order of subjects, with notes. Volume 1. London: J. Butterworth and Son.

Frost, N. 2011. Qualitative research methods in psychology: Combining core approaches. Maidenhead: Open University Press.

Hampden-Thompson, G. and C. Galindo. 2015. Family structure instability and the educational persistence of young people in England. British Educational Research Journal, 41 5, 749-766.

Hinton-Smith, T. (ed.) 2012. Widening Participation in Higher Education: Casting the Net Wide? Basingstoke: Palgrave Macmillan.

Hirst, J. 2013. Welfare underpins the regular abuse of children. The Sydney Morning Herald, 16 January [online]. Available at: http://www.smh.com.au/federalpolitics/political-opinion/welfare-underpins-the-regular-abuse-of-children20130115- 2crh2.html [Accessed 1 December 2014].

Jensen, T. 2014. Speaking back to stigma: Social housing and solidarity in East London. Discover Society, 4 November [online]. Available at: http://www.discoversociety.org/2014/11/04/speaking-back-to-stigmasocial- housing-and-solidarity-in-east-london/ [Accessed 12 March 2015].

Lawler, S. 1999. 'Getting out and getting away': Women's narratives of class mobility, Feminist Review, 63, 3-24.

Maplethorpe, N., J. Chanfreau, D. Philo, and C. Tait. 2010. Families and children in Britain: findings from the 2008 Families and Children Study FACS. London: Department for Work and Pensions.

Martin, M. A. 2012. Family structure and the intergenerational transmission of educational advantage. Social Science Research, 41 1, pp. 33-47.

Merton Historical Society. 2001. Bulletin 138. Merton Historical Society, June [online]. Available at: http://www.mertonhistoricalsociety.org.uk /doc_library/1236Statute.pdf [Accessed on 18 September 2015].

Murphy, T. and A. Kroll. 2012. 'Santorum: Single moms are 'breeding more criminals" Mother Jones, 6 March [online]. Available at: http://www.motherjones.com/politics/2012/03/santorum-single-mothers-arebreeding-more-criminals [Accessed on 4 November 2014].

Office for National Statistics. 2012. Families and households, 2001 to 2011. Newport: Office for National Statistics.

Parliament of Great Britain. 1773. A bill for better regulating the settlement and providing for the maintenance of bastard children.

Reinhold, S. 1994. Through the Parliamentary looking glass: 'Real' and 'Pretend' families in contemporary British politics. Feminist Review, No. 48, pp. 61- 79

Ridge, T. and J. Millar. 2011. Following families: Working lone-mother families and their children. Social Policy and Administration, 45 1, 85-97.

Ringback Weitoft, G., A. Hjern, and M. Rosen. 2004. School's out! Why earlier among children of lone parents? International Journal of Social Welfare, 13, pp. 134144. 
Rowling, J. K. 2010. The single mother's manifesto. The Times, 14 April [online]. Available at: http://www.timesonline.co.uk/tol/comment/columnists/ guest_contributors/article7096786.ece [Accessed on 14 October 2010].

Skeggs, B. 1997. Formations of class and gender: Becoming respectable. London:Sage.

Spillers, H. J. 1987. Mama's baby, papa's maybe: An American grammar book. Diacritics, 172 , 64-81.

Thane, P. and Evans, T. 2012. Sinners? Scroungers? Saints?: Unmarried motherhood in twentieth-century England. United Kingdom: Oxford University Press.

The Foundling Museum. 2015. Wall text, 'The Fallen Woman' exhibition, London, United Kingdom, temporary exhibition 25 September 2015 to 3 January 2016.

The Rush Limbaugh Show. 2013. Radio programme, Premiere Radio Networks, New York, NY, 8 November. Broadcast transcript [online]. Available at: http://www.rushlimbaugh.com/daily/2013/11/08/cuccinelli_won_the_wh olesome_in_droves [Accessed on 2 December 2013].

Yukins, E. 2002. Acts of testimony: Bastard daughters and the possession of history in Corregidora and Paradise. Signs, 28 1, 221-247.

Yuval-Davis, N. 2006. Intersectionality and feminist politics. European Journal of Women's Studies, 133 , 193-209. 